\title{
Influence of habitat structure on the fish prey consumption by largemouth bass, Micropterus salmoides, in experimental tanks
}

\author{
Francisco Nunes Godinho $^{1,2, *}$ and Maria Teresa Ferreira ${ }^{2}$ \\ 1 Centro de Estudos Florestais - Departamento de Engenharia Florestal, Instituto Superior de Agronomia, Tapada \\ da Ajuda, 1349-017 Lisboa, Portugal. \\ 2 Conselho Nacional da Água, Rua de S. Domingos a Lapa, n. ${ }^{\circ}$ 26, 1200-835 Lisboa, Portugal. \\ * Corresponding author: francisco.godinho@sg.maotdr.gov.pt
}

\begin{abstract}
Influence of habitat structure on the fish prey consumption by largemouth bass, Micropterus salmoides, in experimental tanks

The largemouth bass, Micropterus salmoides, was introduced into the Iberian Peninsula in the 50's and has developed important populations in systems naturally lacking native piscivores. As a consequence, the displacement of native cyprinids has been associated with its predatory behaviour, particularly in reservoirs. In order to study the capture rate of largemouth bass in relation to an Iberian native cyprinid, Squalius alburnoides, and also to pumpkinseed, Lepomis gibbosus -another exotic species introduced to Iberia that is able to coexist sucessfully with bass in Iberian systems-tanks were used to simulate the absence of structure, and the presence of vegetation struture and bottom structure. The number of fish captured by largemouth bass were influenced by both structure and prey effects, as well as by their interaction. The bottom and vegetation structure reduced the number of pumpkinseed captured when compared with the absence of structure, whereas only the vegetation reduced the number of Squalius alburnoides captured. Neither the pumpkinseed nor the cyprind were eaten more frequently by largemouth bass in the absence of structure or in the vegetation structure, but the cyprinid was eaten more frequently in the bottom structure.
\end{abstract}

Key words: Largemouth bass, pumpkinseed, iberian cyprinids, habitat.

\section{RESUMEN}

Influencia de la estructura del hábitat en el consumo de peces presa por la perca americana, Micropterus salmoides, en experimentos en tanques

El black bass, Micropterus salmoides, fue introducido en la Península Ibérica en los años 50 y ha desarrollado importantes poblaciones en sistemas naturalmente carentes de ictiófagos nativos. Como consecuencia, el aparente desplazamiento de los ciprínidos nativos ha sido asociado con su comportamiento predador, particularmente en embalses. Con el objetivo de estudiar la captura del black bass sobre un ciprínido ibérico nativo, el calandino, Squalius alburnoides y sobre el pez sol, Lepomis gibbosus -otra especie exótica introducida en Iberia que es capaz de coexistir con éxito con el black bass en los sistemas ibéricos- se utilizaron tanques simulando tres situaciones: ausencia de estructuras, estructuras vegetales y estructuras de ladrillos. Se comprobó que el número de peces capturados por el black bass estaba influenciado por el efecto de las estructuras y de las presas, así como por su interacción. Las estructuras vegetales y de ladrillo provocaban una reducción en el número de pez sol capturadas en comparación con la ausencia de tales estructuras, mientras que instalando sólo estructuras vegetales el número de calandinos, Squalius alburnoides, capturados disminuía. El black bass no capturó ninguna de las dos especies en mayor número en ausencia de estructuras o en estructuras vegetales, pero capturó el calandino mas frecuentemente en presencia de estructuras de ladrillo.

Palabras clave: Black bass, pez sol, ciprínidos nativos, hábitat. 


\section{INTRODUCTION}

In southern Iberia, the primary piscivorous (sensu Keast 1985) largemouth bass, Micropterus salmoides, was introduced in the fifties into native fish communities naturally lacking this type of predatory fish (Almaça, 1983 and 1986; Collares-Pereira, 1985; Elvira 1995a). Since then it has rapidly spread and has long been blamed as the main cause for the apparent displacement of small sized endemic cyprinids in central and southern basins (Almaça, 1983; Elvira 1995a; Pires et al., 1999). For example, in a southern basin, assemblages of endemic small sized cyprinids were found to be spatially segregated from largemouth bass as well as from pumpkinseed sunfish, Lepomis gibbosus, another North American centrarchid later introduced into Iberia (Almodóvar \& Elvira, 1994; Godinho et al., 1997a). This other exotic species rapidly became associated with largemouth bass both in reservoirs and rivers (Braband \& Saltveit, 1989; Almodóvar \& Elvira, 1994; Godinho \& Ferreira, 1997; Godinho et al., 1997a and 1998) and it is presently the bass' chief prey in southern aquatic systems (Godinho \& Ferreira, 1994 and 1997, Nicola et al., 1996; Godinho et al., 1997b). Nevertheless, some field data has suggested that bass may favour the endemic cyprinids over pumpkinseed as prey (Godinho et al., 1997b).

The present rare coexistence of largemouth bass and small Iberian cyprinids, given the bass' apparent selection for these, and the positive association of bass and pumpkinseed, could suggest a distinct capture success of bass of both prey types. Furthermore, in the correlative studies of Godinho \& Ferreira (1994) and Godinho et al. (1997b), fish prey were eaten less frequently when submerged macrophytes were abundant. Experimental studies have also revealed that increasing levels of structural complexity, in the form of submerged vegetation, influences bass foraging rate for other fish prey species such as the pumpkinseed congeneric, and the bluegill, Lepomis macrochirus (Gotceitas \& Colgan, 1989; Savino \& Stein 1982, 1989a and 1989b).

In this study we tested the effects of different prey types, pumpkinseed vs endemic Iberian
Table 1. Two-way ANOVA for the effects of prey and structure type on the foraging rate (number of fish eaten during 21 hours) of largemouth bass in experimental tanks. ANOVA de dos factores para los efectos de la presa y el tipo de estructura sobre la tasa de capturas (número de peces consumidos en 21 horas) por los black bass en los tanques experimentales.

\begin{tabular}{lcccc}
\hline & $\boldsymbol{d} \boldsymbol{f}$ & Mean square & $\boldsymbol{F}$ & $\boldsymbol{p}$ \\
\hline Prey (pumpkinseed vs & & & & \\
cyprinids) & 1 & 10.80 & 16.20 & $<0.001$ \\
Structure type & 2 & 13.73 & 20.60 & $<0.001$ \\
Prey $\times$ structure type & 1 & 2.80 & 4.20 & $<0.05$ \\
Residual & 24 & 0.67 & & \\
\hline
\end{tabular}

cyprinid, and aquatic structure types, on the foraging rate of largemouth bass in experimental feeding trials. So far, the controled experiments conducted to analyse the effects of habitat structure on largemouth bass capture rates for fish prey have only considered different densities of submerged macrophytes (Savino \& Stein, 1982; Schramm \& Zale, 1985; Gotceitas \& Colgan, 1989; Savino \& Stein, 1989a and 1989b). Since distinct types of structure influence the foraging rate of other fish predators differently (Christensen \& Persson, 1993), we investigated not only the effects of vegetation structure but also those of bottom structure.

\section{MATERIAL AND METHODS}

Experiments were conducted in three outdoor shaded plastic tanks (white walls, $1 \mathrm{~m}^{2}, 0.5 \mathrm{~m}$ deep with rounded edges) located in Tapada da Ajuda, Lisboa Portugal, during the Autumn. Three kinds of aquatic structure were tested: no structure, simulated vegetation (henceforth referred to as vegetation structure) and simulated bottom crevices (henceforth referred to as bottom structure). The vegetation structure consisted of $0.5 \mathrm{~m}$ strings (4 $\mathrm{mm}$ in diameter) of green polypropylene attached to the bottom and covering $1 / 4$ of the tank area (i.e. $0.25 \mathrm{~m}^{2}$ ) with a density of 1000 stems $\mathrm{m}^{-2}$, a density previously found to provide effective refuge from bass predation for the bluegill (Savino \& Stein, 1982). The bottom structure consisted of one brick $0.30 \times 0.15 \times 0.40 \mathrm{~m}$ presenting $5 \times 3$ squared holes with $50 \mathrm{~mm}$ sides. The brick was 


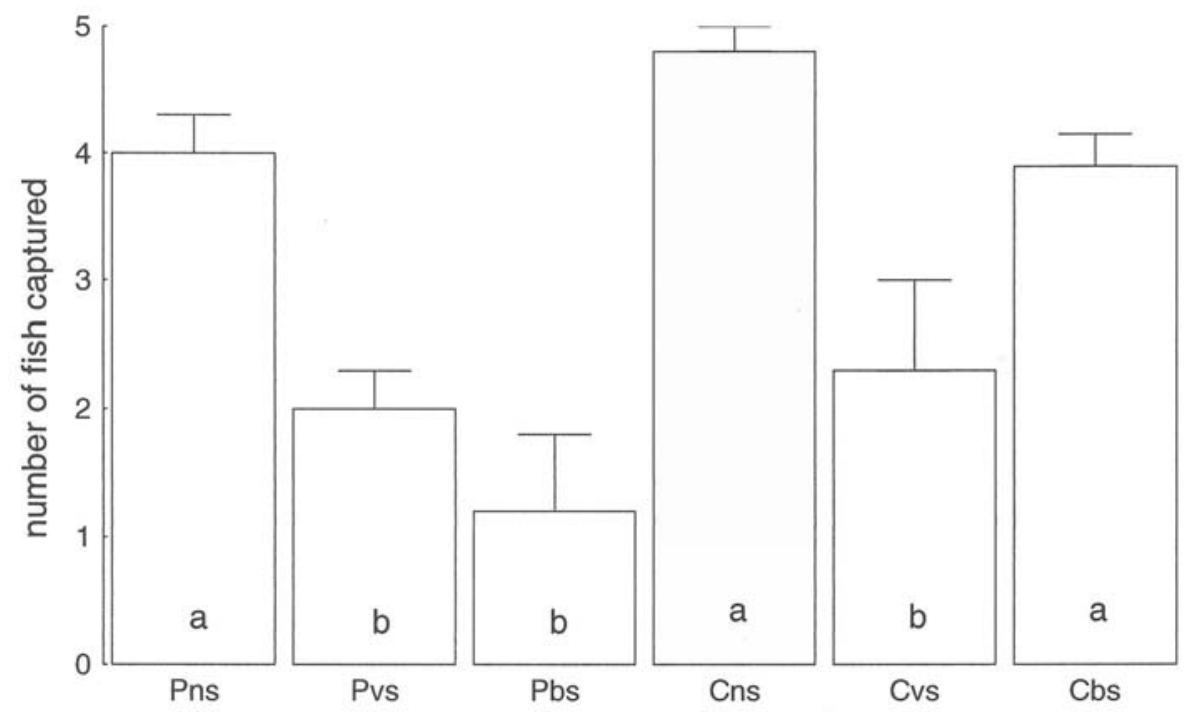

Figure 1. Number (mean of five replicates $\pm 1 \mathrm{SE}$ ) of fish captured during 21 hours by largemouth bass in tanks simulating different structure types. P-pumpkinseed, and C-Cyprinid, whereas ns-no structure, vs-vegetation structure and bs-bottom structure. Letters for prey and structure types are combined to represent a particular treatment. Bars within a prey type followed by the same letter are not significantly different (post-ANOVA Tukey HSD, $p>0.05$ ). Número de peces (media de cinco replicas \pm 1 SE) capturados durante 21 horas por los black bass en los tanques simulando diferentes tipos de estructuras. P-caladinos, y C-ciprinídos, mientras que $n s$-sin estructura, vs-estructura con vegetación y bs-estuctura en el fondo. Las letras para las presas y el tipo de estructuras estan combinadas para presentar un determinado tipo de tratamiento. Las barras dentro de un tipo de seguidas de la misma letra no son significativamente diferentes (a partir de un ANOVA Tukey HSD, $p>0.05$ ).

placed at the bottom of the tank against one of the tank sides and it allowed the access of prey to the holes but not of bass. The bottoms of all tanks were covered by a layer of gravel.

Fishes used in the experiments were collected in nearby rivers and ponds by electrofishing and seine nets. Besides largemouth bass (275-280 $\mathrm{mm}$ in total length TL) and pumpkinseed (40$75 \mathrm{~mm}$ in TL), one Iberian cyprinid was used, the Iberian roach, Squalius alburnoides (40-80 $\mathrm{mm}$ in TL). This cyprinid is widespread in Iberia and often dominates native fish assemblages (Doadrio et al., 1991; Peris et al., 1994; CollaresPereira et al., 1995; Elvira 1995b).

All the fishes were housed in the experimental area where they were acclimatized to existing conditions for two months before use. During that period, bass were fed pumpkinseed and roach, whereas the cyprinid and pumpkinseed ate frozen adult Artemia salina and pieces of earthworm. Each individual bass was allowed to feed in the three structure types at least six times before the experiment began. Tanks were oxyge- nated (to about $7 \mathrm{mg} / \mathrm{l}$ ) with a pump and $20 \%$ of the water in each tank was renovated between trials. Turbidity was always below 4 JTU.

Capture rates were examined in single prey type trials (with either five pumpkinseed or five roach) and in mixed prey type trials (with five pumpkinseed plus five roach).

Each trial began when naive prey were released (after 15 min aclimatization in a plastic bag) with a bass starved for 24 hours (previously acclimatized for two hours) in a tank presenting one of the structure types tested. Trials began at 2p.m. (local time) after prey fish had been released in the tank and ended at 11a.m. the next day, i.e. after 21 hours. At the end of the experiment each bass was feed to satiation and the surviving prey counted. Further, the location of the tank occupied by surviving prey was noted.

The different structure types, as well as prey types (in the single prey type trials), were randomnly assigned to each of the three tanks available before each trial. The six bass used were divided in two groups of three and each 
group was used during each day. Within a group, each bass was randomly assigned to the treatments being tested in a particular day. In the single prey experiments all treatments were replicated 5 times. Mixed prey trials were replicated five or six times. The effects of structure and prey type (i.e. pumpkinseed or Iberian cyprinid) on the foraging rate of largemouth bass (in the single prey experiments) were analysed with a two-way ANOVA and postANOVA Tukey HSD tests (Wilkinson, 1990). No differences were noted in the overall foraging rate for both prey and structure type between the two bass groups ( $p>0.05$ in-all comparisons) and the data was therefore lumped for analysis.

\section{RESULTS}

Daily fluctuations in the water temperature during the course of the experiment were wide (from a minimum of $15{ }^{\circ} \mathrm{C}$ to a maximum of $24{ }^{\circ} \mathrm{C}$ ) and were mainly a consequence of the daily normal oscillations of the air temperature occuring in Portugal at this time of the year. Nevertheless, minimum as well as maximum water temperatures (measured with maximumminimum thermometers) were not significantly different in the various treatments $(p>0.05)$. Moreover, bass appeared to forage willingly while facing the experimental conditions.

Overall, the two factors tested, as well as their interaction, influenced the number of fish captured by bass (Table 1), with the cyprinid being captured in higher numbers than the pumpkinseed (Fig. 1). The presence of both bottom and vegetation structures reduced the number of pumpkinseed captured by bass when compared with the numbers captured in the absence of any structure. In contrast, only the vegetation structure significantly reduced the number of cyprinid captured by bass. All survivors (both prey types) collected in the vegetation and bottom structures were within the vegetation patch or inside the brick holes. The few survivors collected in the absence of structure were allways at the tank bottom edge.

In the mixed prey trials no preference (i.e.,
Table 2. Number of mixed prey type trials where largemouth bass took higher, equal, or lower numbers of pumpkinseed than cyprinid. Número de experimentos con mezcla de presas en los que los black bass atraparon un número mayor, menor o igual de caladinos que ciprínidos.

\begin{tabular}{lccc}
\hline & $\begin{array}{c}\text { No } \\
\text { structure }\end{array}$ & $\begin{array}{c}\text { Vegetation } \\
\text { structure }\end{array}$ & $\begin{array}{c}\text { Bottom } \\
\text { structure }\end{array}$ \\
\hline Pumpkinseed $>$ cyprinids & 1 & 2 & 0 \\
Pumpkinseed $<$ cyprinids & 4 & 3 & 5 \\
Pumpkinseed $=$ cyprinids & 1 & 1 & 0 \\
\hline
\end{tabular}

more frequent consumption) was detected for either prey (pumpkinseed or cyprinid) in the absence of structure $\left(\chi^{2}=6.44, d f=5\right.$, ANOVA comparing numbers of prey eaten in 21 hours $F$ $=4.16, p=0.07)$ and in the vegetation structure $\left(\chi^{2}=5.86, d f=5, F=0.776, p=0.39\right)$, but cyprinids were eaten more frequently in the bottom structure $\left(\chi^{2}=-16.5, d f=4 ; F=\right.$ 14.6, $p=0.005)$. Nevertheless, the cyprinid was taken in higher numbers than the pumpkinseed in more trials (Table 2).

\section{DISCUSSION}

In general, the results obtained in this study support the largemouth bass patterns of fish prey use observed in southern Iberia, with endemic cyprinids being captured at higher rates than the pumpkinseed (Godinho et al., 1997b). In North American rivers and lakes, species of small cyprinids are also captured faster than both the bluegill and pumpkinseed (Savino \& Stein, 1989; Hambright et al., 1991; Mittelbach et al., 1995). In fact, small sized North American species of Cyprinidae such as Pimephales promelas and Notemigonus crysoleucas are usually rare in the presence of largemouth bass whereas Lepomis spp. can sustain large populations (e.g. Johannes et al., 1987, Hambright et al., 1991; Mittelbach et al. 1995). These community patterns parallel the present spatial organization observed in many southern Iberian freshwater systems (Almodóvar \& Elvira, 1994; Godinho \& Ferreira, 1994; Godinho et al., 1997a; Pires et al., 1999).

Factors such as the low handling time cyprinids (narrow-bodied with soft fin rays) 
present when compared with the sunfish (deepbodied with spiny fin rays) probably were involved in the bass higher capture rates for the Iberian roach (Hoyle \& Keast, 1987; Hambright, 1991). According to Webb (1986), the deeper body of the bluegill (and the pumpkinseed), compared with the one of a cyprinid ( $P$. promelas), tended to shift the predator attack target from the middle-body towards the head or tail, thereby increasing the number of prey escapes and unsuccessful bass attacks. Behavioural differences between the two prey types could also have resulted in the different capture determined. Non quantitative observations made during the course of our trials suggested that roach and pumpkinseed behave differently in the presence of largemouth bass. For instance, after their introduction into a tank the roach usually wandered and eventually approached bass at a much closer distance than the pumpkinseed. In addition, roach was usually found much closer to the surface whereas pumpkinseed were closer to the bottom.

As already demonstrated in other studies, the capture of fish prey by bass decreases in the presence of dense stands of aquatic plants (Savino \& Stein, 1982, 1989a and, 1989b) and in this study we have shown that it decreases in the presence of bottom structure as well. According to Savino \& Stein (1982), this is mostly caused by the reduction in bass visual contact, and thus encounter rates, with prey. In our study, both the bottom and vegetation structure did indeed reduce pumpkinseed capture rate, and this species quickly sought refuge in the vegetation patch or in the holes. However, only the vegetation structure decreased the capture of Iberian roach. Roach is related to abundant macrophyte stands in Iberian rivers (Collares-Pereira et al., 1995, Godinho et al., 1997) and this association probably reduced their capture rate in the simulated vegetation treatment. In contrast to pumpkinseed, roach did not penetrate the brick holes in the bottom structure (personal observation) and possibly remained as vulnerable in that treatment as it was in the absence of structure. Consequently, bass clearly demonstrated a higher roach consumption when offered together with pumpkinseed in the bottom structure.

Reductions in the predator foraging rate in the presence of structure have been theoretically shown to have a stabilizing effect on predatorprey relationships (Murdoch \& Oaten, 1975), and thus to be important forces in the organization of fish assemblages (Christensen \& Persson, 1993). Structure such as vegetation and rocks are pervasive elements of aquatic freshwater environments (Anderson, 1984), but their relative importance is system specific. In Iberian lowland rivers, to which roach is adapted (Collares-Pereira et al., 1995, Godinho et al. and 1997a), macrophytic cover is usually high (Ferreira, 1994; Ferreira \& Moreira, 1996). River damming, especially for irrigation purposes, results in extreme fluctuations of the water levels in reservoirs (Garcia de Jalón, 1992). Permanent disturbance, apart from other regulation side-effects (Petts, 1988), does not favour the development and permanence of macrophyte stands on reservoir margins, thereby changing the type of aquatic cover from one dominated by vegetation structure to another dominated by bottom structure. Despite the involvement of other factors, we suggest that the habitat alterations resulting from impoudment, that changes the relative vulnerability of different fish prey, contribute to the absence (or low abundance) of roach in reservoirs and the development of abundant pumpkinseed populations in the presence of bass (Godinho et al., 1998).

\section{ACKNOWLEDGMENTS}

We would like to acknowledge Antonio Albuquerque for his useful collaboration during the running of the experiments.

\section{REFERENCES}

ALMAÇA, C. 1983. Contemporary changes in Portuguese freshwater fish fauna and conservation of autochtonous Cyprinidae.-Roczniki Nauk Rolniczych, Seria 9-15. 
ALMAÇA, C. 1986. Fish and their environment in large European river ecosystems Tejo and Guadiana. Sciences de 1' Eau, 7: 3-19.

ALMODÓVAR, A. \& B. ELVIRA. 1994. Further data on the fish fauna catalogue of the natural park of Ruidera lakes (Guadiana river basin, central Spain). Verh. Int. Verein. Limnol., 25: 2173-2177.

ANDERSON, O. 1984. Optimal foraging by largemouth bass in structured environments. Ecology, 65: 851-861.

BRABAND, A. \& S. J. SALTVEIT. 1989. Ecological aspects of the fish fauna in three Portuguese reservoirs. Arch. Hydrobiol., 114: 575-589.

CHRISTENSEN, C. \& L. PERSSON. 1993. Speciesspecific antipredatory behaviours: effects on prey choice in different habitats. Behav. Ecol. Sociobiol., 32: 1-9.

COLLARES-PEREIRA, M. J. 1985. Ciprinídeos do Alentejo. In: Primeiro Congresso sobre o Alentejo. Associação dos Municipeos de Beja, Alentejo, Portugal: 537-545.

COLLARES-PEREIRA, M. J., M. F. MAGALHÃES, A. M. GERALDES, \& M. M. COELHO. 1995. Riparian ecotones and spatial variation of fish assemblages in Portuguese lowland streams. Hydrobiologia, 303: 93-101.

DOADRIO, I., B. ELVIRA, \& Y. BERNAT. 1991. Peces continentales Españoles -Colección Técnica, Instituto Nacional para la Conservation de la Naturaleza. Madrid. 221 pp.

ELVIRA, B. 1995a. Native and exotic freshwater fishes in Spanish river basins. Freshwat. Biol., 33: 103-108.

ELVIRA, B. 1995b. Conservation status of endemic freshwater fish in Spain. Biol. Conserv., 72: 129136.

FERREIRA, M. T. 1994. Aquatic and marginal vegetation of river Divor and its relation with land use. Verh. Int. Verein. Limnol., 25: 2309-2316.

FERREIRA, M. T. \& I. MOREIRA. 1996. The invasive component of a river flora under the influence of Mediterranean agricultural systems. In: Plant Invasions, General Aspects and Special Problems. Pysek, P., K. Prach, M. Rejmánek, \& M. Wade (eds.): 117-127. SPB Academic Publishing, Amsterdan, The Netherlands.

GARCÍA DE JALÓN, D. G., M. G. TANÁGO \& C. CASADO. 1992. Ecology of regulated streams in Spain: An overview. Limnetica, 8: 161-166.
GODINHO, F. N. \& M. T. FERREIRA. 1994. Diet composition of largemouth black bass, Micropterus salmoides Lacèpede in southern Portuguese reservoirs: its relation to habitat characteristics. Fish. Manage. Ecol., 1: 129-137.

GODINHO, F. N. \& M. T. FERREIRA. 1997. The application of size-structure indices to Micropterus salmoides and Lepomis gibbosus as a management tool for southern Iberian reservoirs. Publicaciones Especiales Instituto Español Oceanografia, 21: 275-281.

GODINHO, F. N., M. T. FERREIRA \& R. V. CORTES. 1997a. Composition and spatial organization of fish assemblages in the lower Guadiana basin, southern Iberia. Ecol. Fresh. Fish 6: 134-143.

GODINHO, F. N., M. T. FERREIRA \& R. V. CORTES. 1997b. The environmental basis of diet variation in pumpkinseed sunfish, Lepomis gibbosus, and largemouth bass, Micropterus salmoides, along an Iberian river basin. Env. Biol. Fish., 50: 105-115.

GODINHO, F. N., FERREIRA, M. T. \& PORTUGAL-CASTRO M. I. 1998. Fish assemblage composition in relation to environmental gradients in Portuguese reservoirs. Aquatic Living Resources, 11: 325-334.

GOTCEITAS, V. \& P. COLGAN. 1989. Predator foraging success and habitat complexity: quantitative test of the threshold hypothesis. Oecologia, 80: 158-166.

HAMBRIGHT, K. D. 1991. Experimental analysis of prey selection by largemouth bass: role of predator mouth width and prey body depth. Trans. Amer. Fish. Soc., 120: 500-508.

HAMBRIGHT, K. D., R. W. DRENNER, S. R. MCCOMAS \& N. G. HAIRSTON JR. 1991. Gapelimited piscivores, planktivore size refuges, and the trophic cascade hypothesis, Arch. Hydrobiol., 121: 389-404.

HOYLE, J. A. \& A. KEAST. 1987. The effect of prey morphology and size on handling time in a piscivore, the largemouth bass (Micropterus salmoides). Can. J. Zool., 65: 1972-1977.

JOHANNES, M. FIT. S., D. J. MCQUEEN, T. J. STEWART \& J. R. POST. 1989. Golden shiner (Notemigonus crysoleucas) population abundance: correlations with food and predators. Can. J. Fish. Aquat. Sci., 46: 810-817.

KEAST, A. 1985. The piscivore feeding guild of fishes in small freshwater ecosystems. Env. Biol. Fish., 12: 119-129. 
MITTELBACH, G. G., M. TURNER, D. J. HALL \& J. E. RETTIG. 1995. Perturbation and resilience: a long term whole-lake study of predator extinction and reintroduction. Ecology, 76: 2347-2360.

MURDOCH, W. W. \& A. OATEN 1975. Predation and population stability. Adv. Ecol. Res., 9: 1-131.

NICOLA, G. G., A. ALMODÓVAR \& B. ELVIRA. 1996. The diet of introduced largemouth bass, Micropterus salmoides, in the natural park of the Ruidera lakes, central Spain. Pol. Arch. Hydrobiol., 43: 179-184.

PERIS, S. J., A. MARTIN \& J. C. VELASCO. 1994. Age, growth and reproduction of the cyprinid Tropidophoxinellus alburnoides (Stephanidis, 1974) in river Agueda, westcentral Spain. Arch. Hydrobiol., 131: 341-352.

PETTS, G. E. 1988. Impounded Rivers. -Wiley, Chichester. 326 pp.

PIRES, A. M., I. G. COWX \& M. M. COELHO. 1999. Seasonal changes in fish community structure of intermittent streams in the middle reaches of the Guadiana basin, Portugal. J. Fish Biol., 54: 235-249.
SAVINO, J. F. \& R. A. STEIN. 1982. Predator-prey interactions between largemouth bass and bluegill as influenced by simulated, submerged vegetation. Trans. Amer. Fish. Soc., 111: 255-266.

SAVINO, J. F. \& R. A. STEIN. 1989a. Behavioural interactions between fish predators and their prey: effects of plant density. Anim. Behav., 37: 311-321.

SAVINO, J. F. \& R. A. STEIN. 1989b. Behavior of fish predators and their prey: habitat. Env. Biol. Fish. 24: 287-293.

SCHRAMM, H. L. \& A. V. ZALE. 1985. Effects of cover and prey size on preferences of juvenile largemouth bass for blue tilapias and bluegills in tanks. Trans. Amer. Fish. Soc., 114: 725-731.

WEBB, P. W. 1986. Effect of body form and response treshhold on the vulnerability of four species of teleost prey attacked by largemouth bass $(M i$ cropterus salmoides). Can. J. Fish. Aquat. Sci., 43: 763-771.

WILKINSON, L. 1990. SYSTAT: the system. for statistics. SYSTAT, Evanston, Illinois, USA. choice between open water and dense vegetation. Env. Biol. Fish., 24: 287-293. 
